\title{
都市部と農村部の $\mathrm{HbA}_{1 \mathrm{c}}$ 值の比較検討について
}

\author{
○長谷川典子* 重住 道彦* 飯田 健一** 佐々木 清**
}

健康診断は, 健康の確認と異常の早期発見さらには早 期治療を目的として実施される屯ので, 予防医学の重要 な一環とされている。ととにタイプIIの糖尿病の初期は 自覚症状がなく, 10 年くらい放置した結果合併症を伴 って診断される場合あ少なくないため, いっそう健康業 務のになうところが大きいかと思われる。

さて今回, 北海道南部にある静内町周辺の農業従事者 250 名を対象にした巡回ドックが行わ!れたので $\mathrm{HbA}_{1}$ 。 及び血糖值を测定し, 潜在的な糖尿病の有無を都市部と 比較してみた。

\section{成 績}

都市部の $\mathrm{HbA}_{1 c}$ は $\bar{x}=5.79 \% \mathrm{HbA}_{1} \bar{x}=6.62 \%$ 空腹 時血糖 $\bar{x}=97.3 \mathrm{mg} / \mathrm{dl}$ 農村部の $\mathrm{HbA}_{1 c}$ は $\bar{x}=5.74 \%$ $\mathrm{H}_{\mathrm{b}} \mathrm{A}_{1} \bar{x}=6.55 \%$ 空腹時血糖 $\bar{x}=96.9 \mathrm{mg} / \mathrm{dl}$ と両者に 全く差が認められなかった。 $\mathrm{HbA}_{1 c}$ のヒストグラムに おいてす, 都市部ではピークが $5.6 \%$ のところにあり, 農村部では $5.4 \%$ に位置していた。巡回ドックでは空腹 時血糖のみを測定しているため, 血糖值には現われず $\mathrm{HbA}_{1} c$ 高值の屯のが 4 例 (1.6\%) あった。当健康管理 センター受診の都市部在住者では, $\mathrm{HbA}_{1 c}$ 高值のあの は全て負荷後 1 時間の血糖値でとらえられていた。当施 設の $\mathrm{HbA}_{1 c}$ の正常值は 4.9\%〜6.6\% だが, 7.0\%を 越えるものは, 都市部で 6 例 (2.4\%) 農村部で 8 例 (3.2 \%)と両者に差は認められなかった。

\section{考 察}

アメリカにおいて 40 才以上の $13 \%$ が糖尿病である といわれ，日本においても中高年がふえるに従い，少な くとも 100 万人はいると言う。その中でタイプIIの糖尿 病は $90 \%$ を占めており，また，診断基準によっては 200 万人になるとあ言われる。さらに糖尿病になる素質 は 5 人に 1 人の割で持っているため, 定期検診及び巡回 ドックによる早期発見が大変重要と考える。

今回, 都市部においては高脂食のとりすぎ, 肥満, 農 村とは違ったストレスの積み重なりがあると考え, 農村 部に比へ，潜在的な糖尿病が多いであろうと札幌市在住 の主に公務員 250 名を選び比較したが, 全く差がみられ なかった。乙れは, 両者を区別する生活スタイル, 食生 活などの要因が現在では存在しにくく, 地域を問わず, 男女を問わず発症してきてると考えられる。また, 糖尿 病患者の $85 \%$ 以上は発症前に肥満していたと言われる ので, これを機会に, 今後は当センター受診者及び農村 部の男女差の肥満及び糖尿病との関連など検討を加えて いきたいと思う。

\section{まとめ}

都市部と農村部の $\mathrm{HbA}_{1 c}$ 值及び血糖值を比較したが が，両者に差が認められなかった。又，血糖值に $\mathrm{HbA}_{1}$ を組み合わせる必要性において，健診車による農村部の 巡回ドックなど空腹時血糖だけ測定せざるを得ない場合 いは, $\mathrm{HbA}_{1 c}$ 值が重要と思われる。

\section{Comparison between Rural Area and City}

** 札幌厚生病院 